\title{
TINGKAT KEBERTERIMAAN TERJEMAHAN ISTILAH BUDAYA OSING: SEBUAH STUDI KASUS TERPANCANG
}

\author{
Wiwin Indiarti dan Wulan Wangi \\ Universitas PGRI Banyuwangi
}

\begin{abstract}
Abstrak
Artikel ini didasarkan pada penelitian yang menggunakan pendekatan deskriptif-kualitatif dengan disain studi kasus terpancang dan berorientasi pada produk penerjemahan. Tujuannya adalah menilai tingkat keberterimaaan terjemahan istilah budaya Osing (Using) yang terdapat pada 3 publikasi pariwisata dwibahasa yang secara resmi diterbitkan oleh Dinas Kebudayaan dan Pariwisata Kabupaten Banyuwangi berdasarkan ideologi yang dianut serta strategi penerjemahan yang diterapkan oleh penerjemah. Parameter yang dipakai untuk menilai tingkat keberterimaan diadopsi dari Instrumen Pengukur Tingkat Keberterimaan Terjemahan milik Prof. Nababan. Hasil studi menunjukkan bahwa terjemahan istilah budaya Osing ke dalam Bahasa Inggris dalam sumber data primer memiliki tingkat keberterimaan yang tergolong tinggi karena keberpihakan penerjemah terhadap budaya dan bahasa sasaran (pembaca sasaran/turis asing) yang dibuktikan dengan pilihan ideologi domestikasi dan strategi penerjemahan yang sesuai, yaitu transposisi (90 kali), sinonim (69 kali), padanan deskriptif (26 kali), penambahan-semantik (23 kali), penambahan-struktural (13 kali), penyusutan (11 kali), perluasan (10 kali), penghilangan (6 kali), terjemahan resmi (5 kali), analisis komponensial (2 kali) dan padanan budaya (1 kali). Secara lebih rinci penerjemahan 381 data primer menghasilkan 261 data (94,75\%) yang tergolong berterima, 3 data $(0,79 \%)$ kurang berterima, dan 17 data (4,46\%) tidak berterima.
\end{abstract}

Kata kunci: Penerjemahan, Istilah Budaya Osing, Tingkat Keberterimaan

\begin{abstract}
This article is based on a descriptive-qualitative research the design of which is an embedded-case study and oriented on the translation product. It aims at assessing acceptability level of Osing (Using) cultural terms translation found in 3 bilingual tourism publications published officially by Banyuwangi Tourism and Cultural Service based on the translation ideology and procedures applied. Theparameter used to reach the objective is adopted from Prof. Nababan's Acceptability Rating Instrument.

The findings show that the translation level of acceptability considered high since the translator tends to adopt the culture and rules of the target language by choosing domestication ideology and translation procedures fit to the ideology; they are transposition (90 times), synonym (69 times), descriptive equivalent (26 times), omission (23 times), contraction (13 times), semantic addition
\end{abstract}


(11 times), structural addition (10 times), amplification (6 times), established equivalent (5 times), componential analysis (2 times) and cultural equivalent (1 time). In details, the translation of 381 primary data resulted in as many as 261 data (94,75\%) are considered as having high acceptability level, 3 data $(0,79 \%)$ are medium acceptability level and 17 data (4,46\%) are low acceptability level.

Keywords: Translation, Osing Cultural Terms, Level of Acceptability)

\section{Pendahuluan}

\section{A.1. Latar Belakang Masalah}

Di era ketika globalisasi semakin mengaburkan batas-batas geografis, ternyata penerjemahan masih menjadi hal yang sangat penting bagi bangsa-bangsa di dunia sebagai sarana komunikasi lintas budaya (cross-cultural communication) demi tercapainya kesepahaman antarbudaya (cross-cultural understanding) karena terjemahan menjembatani perbedaan (gap across cultures) dengan cara meningkatkan pengetahuan mengenai liyan (the others) dan sekaligus mengukuhkan identitas budaya masing-masing.

Banyuwangi, sebuah kota kecil di ujung timur Jawa, meriah dengan perayaan budaya karena menjadi tempat tinggal bagi etnis Osing (Using), Jawa, Madura, Bugis, Tionghoa, Arab, dan Bali. Di antara ketujuh kelompok etnis tersebut, yang dianggap sebagai the natives adalah etnis Osing. Keunikan budaya Osing yang berupa adat tradisi diungkapkan dalam bahasa Osing-bahasa daerah pribumi Banyuwangi. Sebagaimana dinyatakan oleh Catford (1965: 27 dalam Silalahi, 2009: 22), bahwa tiap-tiap bahasa itu tidak sama dengan bahasa lainnya alias "sui generis," maka hal tersebut melahirkan kesulitan tersendiri bagi penerjemah dalam proses pengalihbahasaan karena kemungkinan munculnya masalah ketakterjemahan linguistik (linguistic untranslatability) dan ketakterjemahan budaya (cultural untranslatability).

Kompleksnya masalah dan proses penerjemahan konsep-konsep yang terkait erat dengan budaya serta kenyataan bahwa Banyuwangi merupakan kota yang kaya budaya menjadi titik tolak penelitian dengan rumusan masalah sebagai berikut: "Bagaimanakah tingkat keberterimaan terjemahan istilah budaya Osing yang terdapat pada 3 publikasi pariwisata dwibahasa Kabupaten Banyuwangi ditinjau dari pilihan ideologi penerjemah serta strategi penerjemahan yang diterapkannya?"

\section{A.2. Landasan Teoretis}

\section{A.2.1. Ideologi Penerjemahan}

Ideologi penerjemahan, atau dalam Approaches to Translation (Newmark, 1988: 81 dalam Ordudari, 2007) lebih sering disebut sebagai metode penerjemahan, merujuk pada cara menerjemahkan seluruh teks. Lebih khusus, Newmark memperkenalkan Diagram $V$ untuk menunjukkan dua kutub yang berbeda dari metode penerjemahan. Kutub yang pertama berpihak pada sistem dan budaya bahasa sumber (untuk selanjutnya disingkat BSu) sedangkan kutub yang kedua sangat menghargai sistem dan budaya bahasa sasaran (untuk selanjutnya disingkat BSa). 
Word-for-word translation

Literal Translation

Faithful Translation

Semantic Translation
Adaptation

Free Translation

Idiomatic Translation

Communicative Translation

Gambar 1. Diagram V Metode Penerjemahan (Newmark, 1988: 45)

Secara tradisional, seperti tampak pada model proses penerjemahan yang ditawarkan oleh Newmark, pembicaraan mengenai ideologi atau metode penerjemahan selalu berkutat pada dua pilihan: penerjemahan secara harfiah atau secara bebas. Dikarenakan hakikat penerjemahan sebagai komunikasi lintasbahasa, maka perdebatan mengenai penerapan metode penerjemahan secara harfiah atau bebas bersumber pada perbedaan ekspresi linguistik.

Pada masa sekarang pilihan metode penerjemahan bukan lagi penerjemahan harfiah atau bebas, tetapi penerjemahan domestikasi (domestication) atau foreinisasi (foreignization) karena telah dipahami bersama bahwa penerjemahan tidak bisa tidak dipengaruhi oleh budaya BSu dan BSa sehingga cara menangani hal tersebut menjadi salah satu perhatian utama dalam penerjemahan. Seorang penerjemah harus menentukan prioritas-apakah berorientasi pada BSu dengan menerapkan metode foreinisasi atau pada Bsa dengan metode domestikasi. Dengan kata lain, ideologi dalam penerjemahan memberikan pandangan super makro dalam hubungannya dengan penerjemahan sebagai bagian dari kegiatan sosial budaya (kebudayaan suatu masyarakat (Hoed, 2003 dalam Silalahi, 2003: 68).

Sebagaimana disampaikan sebelumnya, istilah strategi, prosedur, maupun teknik penerjemahan seringkali digunakan secara bergantian untuk merujuk pada cara menerjemahkan kalimat dan unit-unit bahasa yang lebih kecil. Para pakar memiliki pendapatnya masing-masing mengenai seberapa banyak jumlah strategi penerjemahan. Dalam penelitian ini dipakai kategorisasi yang dibuat oleh Zuchridin Suryawinata, Guru Besar Penerjemahan Universitas Negeri Malang. Suryawinata membagi strategi penerjemahan menjadi 2, yaitu strategi struktural dan semantik, berdasarkan pertimbangan bentuk (form/surface structure) dan makna (meaning/ deep structure) bahasa.

\section{A.2.2. Strategi Penerjemahan}

\section{- Strategi Struktural}

Strategi-strategi yang dipaparkan berikut ini bersifat wajib dipilih untuk menca pai efek kewajaran atau keberterimaan secara struktural di dalam BSa.

1. Strategi penambahan (addition) dilakukan dengan menambahkan kata-kata di dalam BSa karena struktur BSa memang menghendaki demikian.

2. Strategi pengurangan (subtraction) dilakukan dengan mengurangi elemen struktural di dalam BSa.

3. Strategi transposisi (transposition) diterapkan pada penerjemahan klausa atau kalimat dengan merubah kategori gramatikal atau mengganti satu kelas kata dengan kelas kata yang lain tanpa merubah makna pesan (Vinay dan 
Dalbernet, 1977: 50 dalam Fernandez-Guerra, 2012). Strategi transposisi harus dilakukan bila terdapat salah satu dari tiga perbedaan antara struktur BSu dan BSa (Newmark, 1988: 85; Rachmadi, 1988: 136 dalam Suryawinata, 2003: 68), yaitu 1) pengubahan bentuk jamak menjadi bentuk tunggal atau sebaliknya; 2) pengubahan posisi kata sifat, 3) pengubahan struktur kalimat secara keseluruhan karena struktur kalimat BSu tidak ada di dalam BSa. Sementara itu Strategi transposisi yang dilakukan karena pertimbangan stilistika mencakup pemecahan satu kalimat BSu menjadi dua kalimat dalam BSa atau lebih dan juga sebaliknya (Newmark, 1988: 85 dalam Suryawinata, 2003: 69).

\section{- Strategi Semantis.}

1. Strategi Pungutan. Strategi ini dibedakan menjadi 2, yaitu transliterasi atau pungutan murni dan naturalisasi. Transliterasi biasanya diterapkan apabila kata atau ungkapan dalam BSu yang tidak ada padanannya dalam budaya BSa atau bila penerjemah ingin menciptakan efek stilistika atau eksotika (FernandezGuerra, 2012) Sementara itu naturalisasi diterapkan dengan melakukan adaptasi morfologis atau fonetis pada ejaan kata atau ungkapan.

2. Strategi padanan budaya diterapkan dengan mengganti kata/istilah yang khas dalam BSu dengan kata/istilah yang khas dalam BSa. Strategi ini kemungkinan besar tidak bisa menjaga ketepatan makna karena budaya BSu seringkali berbeda dengan budaya BSa. Karena tujuan utamanya adalah domestikasi (FernandezGuerra, 2012), maka strategi ini bisa menghasilkan terjemahan yang mulus dan enak dibaca (Suryawinata, 2003: 72).

3. Padanan Deskriptif dilakukan dengan mendiskripsikan makna atau fungsi dari istilah/ungkapan sehingga sejenis dengan parafrase, atau bahkan amplifikasi atau eksplanasi dari istilah BSu (Suryawinata, 2003: 73).

4. Analisis komponensial sangat mirip dengan padanan deskriptif. Dalam hal ini sebuah kata dalam BSu diterjemahkan dengan cara memerinci komponenkomponen makna kata BSu tersebut karena padanannya tidak ditemukan dalam Bsa sementara penerjemah menganggap bahwa pembaca perlu mengerti makna yang sebenarnya.

5. Penghapusan (omission/deletion) dilakukan dengan menyintesiskan atau mengimplisitkan informasi dalam BSu, terutama bila informasi tersebut dianggap tidak penting (Vázquez Ayora, 1977: 359 dalam Fernandez-Guerra, 2012). Strategi penerjemahan ini tidak biasa diterapkan untuk menerjemahkan istilah-istilah budaya karena biasanya istilah budaya tersebut tidak relevan fungsinya atau malah menyesatkan pembaca (Fernandez-Guerra, 2012).

6. Modulasi (modulation) diterapkan dengan menggunakan frase yang berbeda untuk mengungkapkan ide yang sama. Atau dengan kata lain terjadi perubahan fokus, sudut pandang, perspektif atau cara berpikir pada diri penerjemah (Newmark, 1988: 88 dalam Suryawinata, 2003: 75).

7. Terjemahan Resmi yang telah dibakukan disatukan dalam Pedoman Pengindonesiaan Nama dan Kata Asing. Strategi ini diterapkan untuk menerjemahkan istilah asing ke dalam bahasa Indonesia.

8. Penyusutan dan Perluasan. Strategi penyusutan dipakai bila penerjemah menghilangkan elemen kata dalam BSu. 
9. Penambahan. Tidak sama dengan strategi penambahan pada strategi struktural, penambahan yang dilakukan berdasarkan pertimbangan kejelasan makna. Informasi tambahan ini bisa berupa catatan perut, catatan kaki, atau catatan di akhir teks (Newmark, 1988: 91-92 dalam Suryawinata, 2003: 74).

10. Sinonim. Penerjemah juga bisa menerapkan strategi ini apabila analisis komponensial dirasa bisa mengganggu alur kalimat BSa, yaitu dengan cara menggunakan kata BSa yang kurang lebih sama untuk kata-kata BSu yng bersifat umum (Newmark, 1988: 83-84 dalam Suryawinata, 2003: 73).

\section{A.2.3. Tingkat Keberterimaan Terjemahan}

Tingkat keberterimaan terjemahan terkait erat dengan fungsi terjemahan sebagai sarana komunikasi antara penulis asli dengan pembaca sasaran. Fungsi ini pada umumnya dipahami sebagai upaya transfer ilmu pengetahuan, teknologi dan budaya dari suatu bahasa ke bahasa yang lain. Oleh karena suatu terjemahan ditujukan bagi pembaca sasaran, maka terjemahan yang dihasilkan tersebut tidak boleh bertentangan dengan kaidah, norma, dan budaya yang berlaku dalam masyarakat pembaca sasaran. Sudah bisa dipastikan bahwa unsur-unsur kebahasaan yang digunakan oleh penerjemah di dalam terjemahan harus mampu membantu pembaca sasaran dalam memahami terjemahan tersebut dengan mudah. Oleh karenanya dapat disimpulkan bahwa aspek keberterimaan tidak bisa dikesampingkan. Aspek keberterimaan bersama dengan dua aspek lainnya, yaitu keakuratan dan keterbacaan, menjadi parameter dari terjemahan yang berkualitas (Silalahi, 2009: 34-35).

\section{Metode Penelitian}

Penelitian ini termasuk ke dalam jenis penelitian penerjemahan yang berorientasi pada produk atau terjemahan karena yang menjadi fokus adalah terjemahan istilah budaya Osing. Penetapan tersebut dimaksudkan agar kajian bisa dilakukan secara rinci, yang selanjutnya dipakai sebagai landasan untuk menetapkan kesimpulan kajian pada tataran makro, yaitu tataran teks.

Sementara itu, disain penelitian ini merupakan studi kasus tunggal terpancang karena sumber data dan satuan terjemahannya telah ditetapkan sebelum penelitian dilakukan, dan kesimpulan yang ditarik terpancang atau berlaku terbatas pada data penelitian yang dianalisis sehingga hasil penelitiannya tidak bisa digeneralisasikan (Silalahi, 2009: 88).

Data yang digunakan dalam penelitian ini adalah kata atau frasa (istilah) terkait budaya Osing dan terjemahannya dalam bahasa Inggris yang terdapat pada sumber data. Analisis terhadap data tersebut akan mengungkapkan ideologi dan strategi penerjemahan yang diterapkan oleh penerjemah.

Sumber data dalam penelitian ini adalah tiga publikasi pariwisata dwibahasa yang mencakup Visitor's Guide Book: Visit Banyuwangi-The Real Tropical Country (2010), Banyuwangi Calendar of Events (2013), dan brosur Welcome to BanyuwangiThe Sunrise of Java (2013). Ketiga-tiganya diterbitkan oleh Dinas Kebudayaan dan Pariwisata Kabupaten Banyuwangi. Publikasi yang pertama berupa buku panduan perjalanan yang terbagi dalam 6 bab dan terdiri dari 121 halaman. Publikasi kedua 
berupa kalender kegiatan yang terbagi dalam 43 bab dan terdiri dari 57 halaman. Pembagian bab berdasarkan pada jumlah kegiatan yang dipromosikan. Publikasi yang ketiga berupa brosur yang berisi peta kota Banyuwangi, peta wisata Banyuwangi dan informasi bergambar mengenai 26 destinasi wisata yang dipromosikan. Tidak ada keterangan tertulis yang menyebutkan nama penerjemah pada semua jenis publikasi tersebut.

Penelitian ini menggunakan teknik dokumentasi untuk mengumpulkan data yang terkait dengan ideologi dan strategi penerjemahan dalam sumber data. Sementara itu, komponen utama proses analisis dalam penelitian ini adalah 1) reduksi data, 2) sajian data, dan 3) penarikan kesimpulan atau verifikasi (Miles \& Huberman, 1994: 22-23 dalam Silalahi, 2009: 97). Teknik analisis yang digunakan adalah model analisis interaktif (interactive model of analysis). Cara kerja dari model analisis interaktif adalah adanya interaksi antar komponen dengan proses pengumpulan data sebagai proses yang berbentuk siklus. Penelitian ini diawali dengan pengumpulan data. Peneliti bergerak di antara komponen analisis secara interaktif sambil tetap melakukan pengumpulan data. Langkah selanjutnya setelah data terkumpul adalah peneliti hanya bergerak di antara tiga komponen analisis.

Secara umum, prosedur penelitian yang dilaksanakan di Banyuwangi ini secara lengkap bisa disajikan sebagai berikut:

1. Menetapkan sumber data, data, dan satuan terjemahan yang hendak dikaji.

2. Merumuskan masalah dan tujuan penelitian. Pada tahap ini peneliti menyatakan secara jelas masalah-masalah penelitian yang akan membimbing peneliti dalam mengumpulkan data dan mengarahkan peneliti dalam menyusun teori.

3. Mengidentifikasi kategori istilah budaya Osing yang terdapat pada sumber data.

4. Membandingkan istilah budaya Osing pada teks BSu dan teks BSa untuk mengidentifikasi ideologi dan strategi penerjemahan yang diterapkan.

5. Mengkaji tingkat keberterimaan terjemahan berdasarkan Acceptability Rating Instrument milik Prof. Nababan dengan modifikasi.

6. Mengkaji peran ideologi dan strategi penerjemahan terhadap tingkat keberterimaan terjemahan.

\section{Temuan dan Pembahasan}

Bagian ini menggabungkan antara paparan data dan temuan penelitian serta pembahasan atas temuan penelitian tersebut. Pemaparan mengenai jumlah istilah budaya Osing dilakukan paling awal. Alasan yang mendasarinya adalah bahwa data tersebut penting sebagai bahan kajian primer. Selanjutnya disajikan strategi penerjemahan sebelum pengidentifikasian ideologi penerjemahan yang diterapkan karena, sebagaimana telah diterangkan di awal, maka ideologi penerjemahan yang berada pada tataran super makro akan dapat diketahui hanya kalau strategi penerjemahan yang berada pada tataran mikro sudah diidentifikasi terlebih dahulu.

Penerapan ideologi dan strategi penerjemahan pada dasarnya dimaksudkan untuk menghasilkan terjemahan yang berkualitas. Oleh karena itulah, pilihan tentang kedua hal tersebut sangat berperan dalam menentukan kualitas terjemahan. Terjemahan yang berkualitas menuntut pentransferan pesan secara akurat (aspek keakuratan), pengungkapan terjemahan yan sesuai dengan kaidah, norma dan budaya yang berlaku dalam budaya BSa 
(aspek keberterimaan) dan penggunaan aspek-aspek kebahasaan yang mudah dipahami oleh pembaca (aspek keterbacaan). Tingkat kesulitan dalam memahami suatu terjemahan tidak ditentukan pada kadar kesulitan suatu bidang ilmu, namun terkait erat dengan penggunaan aspek kebahasaan, seperti pilihan kata dan frasa (istilah). Namun demikian, sebagaimana telah disampaikan di awal bahwa artikel ini hanya akan menilai tingkat keberterimaan terjemahan.

Data penelitian yang bersumber pada tiga publikasi pariwisata dwibahasa Kabupaten Banyuwangi terdiri atas data bahasa Indonesia yang memuat istilah budaya Osing sebagai data sumber dan data bahasa Inggris sebagai data sasaran. Data sumber yang teridentifikasi berwujud istilah (kata atau frasa) budaya Using.

\section{A.1. Strategi dan Ideologi Penerjemahan yang Diterapkan}

Dari 381 data sumber yang dianalisis, teridentifikasi sebanyak 368 data diterjemahkan dengan menerapkan strategi penerjemahan tunggal dan sebanyak 13 data diterjemahkan dengan menerapkan dua strategi penerjemahan sekaligus (kuplet). Secara keseluruhan, terdapat 12 strategi penerjemahan yang dipakai secara tunggal maupun kuplet, yaitu peminjaman murni, padanan deskritif, sinonim, analisis komponensial, transposisi, penambahan-semantik, penambahan-struktural, perluasan, penyusutan, terjemahan resmi, padanan budaya dan penghilangan.

\begin{tabular}{|c|l|c|c|c|}
\hline \multirow{2}{*}{ No. } & \multirow{2}{*}{$\begin{array}{c}\text { Strategi } \\
\text { Penerjemahan }\end{array}$} & \multicolumn{2}{|c|}{ Varian Strategi } & \multirow{2}{*}{ Jumlah } \\
\cline { 3 - 4 } & & Tunggal & Kuplet \\
& & & & \\
\hline 1 & Peminjaman Murni & 132 & - & 132 \\
\hline 2 & Transposisi & 84 & 6 & 60 \\
\hline 3 & Sinonim & 62 & 7 & 26 \\
\hline 4 & Padanan Deskriptif & 26 & - & 23 \\
\hline 5 & Penambahan (semantik) & 23 & - & 11 \\
\hline 6 & Penyusutan & 11 & - & 13 \\
\hline 7 & Perluasan & 9 & 1 & 6 \\
\hline 8 & Penambahan (struktural) & 8 & 5 & 5 \\
\hline 9 & Penghilangan & 6 & - & 2 \\
\hline 10 & Terjemahan Resmi & 5 & - & 1 \\
\hline 11 & Analisis Komponensial & 2 & - & \\
\hline 12 & Padanan Budaya & 1 & - & \\
\hline
\end{tabular}

Tabel 1. Frekuensi Penerapan Strategi Penerjemahan

Tabel 1 menunjukkan bahwa secara umum strategi penerjemahan yang berorientasi pada budaya dan BSu; yaitu peminjaman murni (pure borrowing), dipakai sejumlah 132 kali $(34,02 \%)$. Sementara itu, frekuensi kemunculan strategi penerjemahan yang berorientasi pada budaya dan BSa; yaitu transposisi, sinonim, padanan deskriptif, penambahan-semantik, penambahan-struktural, penyusutan, perluasan, penghilangan, terjemahan resmi, analisis komponensial dan padanan budaya, adalah sebanyak 256 kali $(65,97 \%)$. Dengan demikian, nampak jelas bahwa penerjemah cenderung menerapkan strategi penerjemahan yang berpihak pada budaya dan kaidah Bsa. Oleh karenanya dapat dinyatakan bahwa ideologi yang dianut oleh penerjemah adalah ideologi domestikasi. 


\section{A.2. Peran Ideologi dan Strategi Penerjemahan terhadap Tingkat Keberterimaan Terjemahan Istilah Budaya Using}

Tujuan dari penelitian ini adalah menilai tingkat keberterimaan terjemahan istilah budaya Osing pada sumber data ditinjau dari ideologi dan strategi penerjemahan yang dipakai oleh penerjemah. Tujuan tersebut didasarkan pada asumsi bahwa disadari atau tidak, seorang penerjemah pasti akan selalu berupaya untuk menghasilkan terjemahan yang berkualitas, dalam kasus ini memiliki tingkat keberterimaan yang tinggi dengan penerapan ideologi dan strategi penerjemahan yang tepat. Namun demikian, suatu strategi penerjemahan tidak selalu berbanding lurus dengan kualitas terjemahan. Jika terjadi yang demikian, maka besar kemungkinan telah terjadi kesalahan dalam penentuan pilihan strategi maupun ideologi.

Suatu terjemahan dikatakan berterima apabila terjemahan tersebut terasa alamiah; istilah yang dipilih lazim digunakan di bidang budaya dan akrab bagi pembaca sasaran: kata atau frasa yang digunakan sudah sesuai dengan budaya dan kaidah-kaidah bahasa Inggris (Nababan, dkk. 2012: 51). Dalam penelitian ini teridentifikasi 361 data (123 kata dan 238 frasa dalam bahasa Osing) yang tergolong terjemahan yang sudah berterima. Sebagian data yang termasuk kategori ini direpresentasikan oleh contoh-contoh berikut.

\begin{tabular}{|l|l|l|}
\hline Bsu & Bsa & Strategi \\
\hline Lepet & Sticky rice wrapped in coconut leaf & Padanan Deskriptif \\
\hline Oncor & Torches & Sinonim \\
\hline Wayang Kulit & Shadow Puppet Show & Sinonim \\
\hline Sang Hyang Iwak & The Sea Goddess & Sinonim \\
\hline Dokar & Horse-carts & Sinonim \\
\hline Using & Usingnese (The Native of Banyuwangi) & Penambahan Semantik \\
\hline Rumah Using & Usingnese Bungalows & Sinonim \\
\hline $\begin{array}{l}\text { Agrowisata Ka- } \\
\text { liklatak }\end{array}$ & Kaliklatak Agro-Tourism & Transposisi \\
\hline
\end{tabular}

Tabel 2. Contoh Istilah Budaya yang Diterjemahkan secara Berterima

Kata lepet diterjemahkan menjadi sticky rice wrapped in cononut leaf dengan strategi padanan deskriptif menghasilkan terjemahan yang berterima karena terjemahan yang dihasilkan memenuhi kaidah BSa dan memang dalam BSa tidak ada padanan budaya bagi nama makanan tradisional tersebut. Oncor, wayang kulit, Sang Hyang Iwak, dokar, dan rumah Using diterjemahkan dengan strategi yang sama; yaitu sinonim, karena penerjemah menganggap bahwa memberikan padanan dengan konsep yang serupa atau mendekati sama sudah cukup informatif bagi pembaca sasaran dan tidak akan menimbulkan pengaruh yang fatal terhadap pemahaman bacaan secara keseluruhan. Istilah Using tidak sekedar diterjemahkan menjadi Usingnese, tetapi diberi tambahan informasi the native of Banyuwangi (dengan menggunakan strategi penambahan semantik) karena pertimbangan bahwa pembaca tidak akan memahami dengan baik arti istilah tersebut tanpa informasi tambahan yang berkaitan dengan maknanya.

Terjemahan yang kurang berterima mengacu pada terjemahan yang pada umumnya sudah terasa alamiah; namun ada sedikit masalah pada penggunaan istilah teknis atau terjadi sedikit kesalahan gramatikal (Nababan, dkk., 2012: 51). Terdapat 3 data (3 frasa) yang tergolong sebagai terjemahan yang kurang berterima; yaitu $23 \mathrm{~d}$, data $5 \mathrm{a}$, dan data $12 \mathrm{~b})$. Terjemahan untuk data nomor $23 \mathrm{~d}$ adalah to read mocking, Penggunaan kata benda 
(mocking) dalam data tersebut kurang tepat karena setelah kata kerja read dibutuhkan keterangan cara (adverb of manner). Terjemahan data 5a adalah Turtle Beach Sukamade. Penerjemahan ini tidak berterima dalam bahasa Inggris karena kata Sukamade yang berfungsi sebagai kata sifat seharusnya diletakkan di posisi terdepan, yaitu Sukamade Turtle Beach. Kasus penerjemahan data nomor $12 \mathrm{~b}$ adalah soal kesalahan dalam pemilihan strategi penerjemahan. Sebenarnya sudah ada keterangan tambahan yang berterima mengenai apa itu Pantai Boom, tetapi sayang istilah Pantai Boom diterjemahkan dengan strategi peminjaman murni sehingga menimbulkan sedikit kebingungan.

Terjemahan tidak berterima atau dikenal juga dengan terjemahan tidak alamiah merupakan terjemahan yang istilah-istilahnya tidak lazim digunakan di bidang budaya dan tidak akrab bagi pembaca sasaran; yang kata maupun frasanya tidak sesuai dengan kaidah bahasa Inggris (Nababan, dkk., 2012: 51). Dalam penelitian ini diidentifikasi sebanyak 17 data (17 frasa) yang termasuk ke dalam terjemahan tidak berterima.

\begin{tabular}{|l|l|l|}
\hline Bsu & Bsa & Strategi Penerjemahan \\
\hline Kiling & Killing & Peminjaman Murni \\
\hline Grajagan & $\begin{array}{l}\text { The name of the bay where the huge } \\
\text { waves found at the South of Banyu- } \\
\text { wangi }\end{array}$ & Padanan Deskriptif \\
\hline
\end{tabular}

Tabel 3. Contoh Istilah Budaya yang Diterjemahkan secara Tidak Berterima

Istilah kiling diterjemahkan dengan strategi peminjaman murni menjadi kiling. Penerjemahan istilah budaya dengan pemakaian strategi peminjaman murni secara tunggal tanpa mengkombinasikannya dengan strategi yang lain riskan melahirkan terjemahan yang tidak berterima karena terjemahan yang dihasilkan seringkali tidak memberikan informasi apa pun yang berharga bagi pembaca sasaran. Untuk nama tempat seperti kasus kata Grajagan apabila diterjemahkan murni dengan strategi padanan deskriptif tanpa strategi peminjaman murni juga menghasilkan terjemahan yang tidak berterima (sama dengan kasus penerjemahan kiling menjadi kiling) karena hanya membuat pembaca bingung.

Hasil penilaian tingkat keberterimaan terjemahan secara utuh diperlihatkan oleh tabel berikut ini:

\begin{tabular}{|c|c|c|}
\hline Terjemahan Berterima & $\begin{array}{c}\text { Terjemahan Kurang Ber- } \\
\text { terima }\end{array}$ & $\begin{array}{c}\text { Terjemahan Tidak Ber- } \\
\text { terima }\end{array}$ \\
\hline 9 & - & - \\
\hline 6 & - & 3 \\
\hline 108 & 1 & 3 \\
\hline 62 & - & - \\
\hline 1 & - & 1 \\
\hline 16 & - & - \\
\hline 4 & - & 6 \\
\hline- & - & $17(4,46 \%)$ \\
\hline $361(94,75 \%)$ & 2 & \\
\hline
\end{tabular}

Tabel 4. Tingkat Keberterimaan Terjemahan

\section{A.2.1. Strategi Penerjemahan}

Sebelumnya telah disampaikan bahwa data penelitian ini berjumlah 381 . Dari 
jumlah tersebut, 368 data diterjemahkan dengan menerapkan strategi penerjemahan tunggal dan sebanyak 13 data diterjemahkan dengan menerapkan strategi penerjemahan kuplet. Tampak jelas bahwa jumlah data yang diterjemahkan dengan strategi penerjemahan tunggal lebih banyak daripada jumlah data yang diterjemahkan dengan strategi penerjemahan kuplet. Hal ini disebabkan karena sifat dari strategi penerjemahan yang diarahkan pada tataran mikro. Dengan lain istilah, bahwa strategi penerjemahan pada lazimnya diterapkan pada satuan lingual yang berada di bawah tataran kalimat atau klausa, yaitu kata atau frasa (dalam hal ini istilah bahasa Using)

Berdasarkan jumlah kemunculannya atau penerapannya pada keseluruhan data penelitian ini diketahui bahwa strategi peminjaman murni menempati urutan pertama (132 kali), yang diikuti oleh strategi transposisi (90 kali), strategi sinonim (69 kali), strategi padanan deskriptif (26 kali), strategi penambahan (semantis) (23 kali), strategi penyusutan (11 kali), strategi perluasan (10 kali), strategi penambahan (struktural) (13 kali), strategi penghilangan (6 kali), strategi terjemahan resmi (5 kali), strategi analisis komponensial ( 2 kali), dan strategi padanan budaya (1 kali).

Tingginya tingkat pemakaian strategi peminjaman murni dalam penelitian ini disebabkan karena penerjemah ingin menciptakan efek eksotika pada bahasa sasaran dengan mempertahankan istilah (kata atau frasa) budaya Osing tanpa ada perubahan apa pun. Diharapkan wisatawan asing yang datang akan mendapatkan gambaran mengenai kekayaan budaya daerah Banyuwangi. Pilihan tersebut sangat bisa dimaklumi karena versi bahasa Inggris dari publikasi pariwisata memang ditujukan bagi warga asing terutama yang berbahasa Inggris. Dalam hal ini penerjemah sudah melakukan pilihan ideologi dan strategi penerjemahan yang tepat. Namun demikian, penggunaan strategi peminjaman murni dengan frekuensi besar secara tunggal (132 kali) merupakan keputusan yang kontraproduktif terhadap tujuan penerjemah menghasilkan terjemahan dengan tingkat keberterimaan tinggi karena yang muncul kemudian hanya kebingungan pembaca sasaran. Bukannya mendapatkan pengetahuan baru mengenai budaya Osing, pembaca bahkan akan lost in translation. Terlalu banyaknya istilah asing (istilah Osing) ternyata berdampak pada sulitnya pembaca sasaran memahami isi dari publikasi pariwisata yang ada. Strategi ini termasuk strategi yang berpihak pada budaya dan bahasa sumber karena tujuan utamanya adalah foreinisasi.

Strategi transposisi menduduki tempat kedua terbanyak digunakan karena perbedaan aturan gramatikal yang dimiliki oleh bahasa sumber (bahasa Using) dan bahasa sasaran (bahasa Inggris). Pada umumnya, bahasa Osing menganut hukum diterangkan menerangkan (DM), sedangkan bahasa Inggris menganut hukum menerangkan diterangkan (MD). Dengan demikian, perubahan susunan kata harus disesuaikan dengan aturan bahasa sasaran, dalam hal ini melalui penerapan strategi transposisi. Jika tidak, maka terjemahan yang dihasilkan tidak akan memiliki tingkat keberterimaan tinggi, dan akan tergolong terjemahan yang kurang atau malah bahkan tidak berterima yang berujung pada kebingungan di pihak pembaca sasaran. Sebagaimana telah diterangkan di awal, strategi transposisi yang dilakukan karena kaidah berbahasa bukan merupakan pilihan, tetapi langkah yang harus diambil; tidak boleh ditawar.

Strategi terbanyak ketiga adalah strategi sinonim. Strategi ini diterapkan karena penerjemah merasa kesulitan untuk mencari padanan budaya yang tepat bagi istilah 
budaya Osing dalam bahasa Inggris. Sementara itu, penerapan strategi padanan deskriptif atau analisis komponensial mungkin bisa mengganggu kenyamanan pembaca. Pilihan ini sangat rasional karena memang perbedaan budaya yang dimiliki oleh bahasa Inggris dan bahasa Osing sangatlah besar. Pilihan ini juga dimungkinkan karena (1) penerjemah merasa enggan untuk melakukan analisis komponensial atau mencari padanan deskriptifnya, atau (2) penerjemah merasa penjelasan yang terlalu detil memang tidak terlalu penting atau mendesak untuk diketahui oleh pembaca sasaran.

Penelitian ini menunjukkan bahwa 1) tujuan dari sebagian besar strategi penerjemahan yang dipakai untuk menerjemahkan istilah budaya pada tiga sumber data adalah domestikasi jadi tingkat keberterimaan dominan dipakai sebagai bahan pertimbangan dan 2) tidak semua strategi yang biasa dipakai untuk menerjemahkan istilah budaya dipakai di sini karena urusan tingkat keberterimaan juga. Perbedaan budaya yang sangat besar antara BSu dan BSa tidak memungkinkan digunakannya, sebut saja misalnya, strategi padanan budaya.

\section{A.2.2 Ideologi Penerjemahan}

Hasil penelitian ini menunjukkan bahwa terdapat dua ideologi penerjemahan yang mendasari proses pengambilan keputusan yang dilakukan penerjemah, yaitu ideologi foreinisasi dan ideologi domestikasi. Kemunculan dua ideologi tersebut mengindikasikan adanya konflik batin yang dialami oleh penerjemah. Di satu sisi dia ingin bersetia pada teks BSu, tetapi di lain sisi dia juga ingin menghasilkan terjemahan yang berterima dan memiliki tingkat keterbacaan tinggi. Namun demikian, analisis data secara keseluruhan menunjukkan dengan jelas bahwa penerjemah cenderung menerapkan ideologi domestikasi. Memang benar bahwa penggunaan ideologi foreinisasi dengan menerapkan strategi peminjaman murni menduduki peringkat teratas dalam hierarki penggunaan strategi penerjemahan terbanyak, tetapi tetap saja apabila keseluruhan strategi yang diterapkan dijumlah dan dibandingkan maka jumlah strategi yang berpihak pada budaya dan kaidah BSa lebih dominan.

\section{Simpulan}

Bertolak dari hasil penelitian, maka dapat ditarik simpulan sebagai berikut: tingkat keberterimaan istilah budaya Osing pada publikasi pariwisata dwibahasa Kabupaten Banyuwangi sangat tinggi, yaitu $94,7 \%$ karena penerapan ideologi domestikasi dan strategi penerjemahan yang berorientasi pada budaya dan kaidah BSa atau berpihak pada pembaca sasaran.

32 | Ranah Volume 4 Nomor 1 Juli 2015 


\section{Daftar Pustaka}

Fernandez-Guerra, Ana B. 2012, Translating Culture: Problems, Strategies and Practical Realities, [sic] A journal of Literature, Culture and Literary Translation, ISSN 1847-7755 (http://www.sic-journal-org/en/past-issues/5/ literary-translation) diakses pada 6 Maret 2013

Nababan, Mangatur, dkk., Pengembangan Model Penilaian Kualitas Terjemahan, Kajian Linguistik dan Sastra, Vol. 24., No. 1, Juni 2012, hlm. 39-57

Ordudari, Mahmoud, Translation Prosedures, Strategies and Methods, Translation Journal and the Author, Vol. 11, No. 3, July 2007 (http://translationjournal. net/journal/41culture.htm) diakses pada 6 Maret 2013

Silalahi, Roswita. 2009. Dampak Teknik, Metode, dan Ideologi Penerjemahan pada Kualitas Terjemahan Teks Medical-Surgical Nursing dalam Bahasa Indonesia. USU Medan (Disertasi)

Suryawinata, Zuchridin dan Sugeng Hariyanto. 2003. Trans/ation: Bahasan Teori dan Penuntun Praktis Menerjemahkan. Yogyakarta: Penerbit Kanisius

----------, 2010. Visitor's Guide Book: Visit Banyuwangi-The Real Tropical Country, Banyuwangi: Dinas Kebudayaan dan Pariwisata Kabupaten Banyuwangi

-------, 2013. Banyuwangi Calendar of Events, Banyuwangi: Dinas Kebudayaan dan Pariwisata Kabupaten Banyuwangi

------ 2013. Welcome to Banyuwangi: The Sunrise of Java (2013), Banyuwangi: Dinas Kebudayaan dan Pariwisata Kabupaten Banyuwangi 